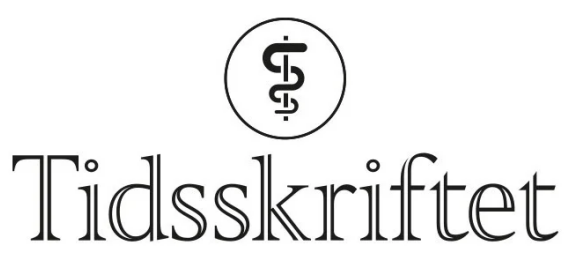

DEN NORSKE LEGEFORENING

\title{
Re: Det er så mye vi ikke vet
}

\author{
BREV TIL REDAKTØREN
}

\section{JOHN-TORE EID}

John-Tore Eid (f. 1952) er stipendiat ved Institutt for Samfunnsmedisin, NTNU Ingen oppgitte interessekonflikter.

Email: john-tore.eid@ntnu.no

Takk for en fin leder om en problematisk helsetilstand som opptar allmennheten, og som i særlig grad utfordrer medisinfaget (1). Lederen trekker fram flere sider ved diagnosen kronisk utmattelsessyndrom/myalgisk encefalopati (CFS/ME), og det stilles flere viktige spørsmål, blant annet om den tradisjonelle biomedisinske, reduksjonistiske modell er egnet til å forstå problemet og gjøre oss i stand til å hele det.

«Det er så mye vi ikke vet» og «kanskje ligger svaret et annet sted enn vi kan forestille oss», skriver Tveito. Her savner jeg at erfaringsperspektivet nevnes mer eksplisitt, som en viktig del av dette omfattende problemet: Det vil si hvordan skjellsettende livserfaringer i menneskers historie og nåværende livssituasjon kan påvirke «den levde kroppen», svekke den og gjøre den syk, for å bruke uttrykket til den franske filosofen Merleau-Ponty (므). Den mangeårige forskningen til Anna Luise Kirkengen gir en grundig dokumentasjon av dette (3).

Jeg har skrevet en artikkel i tidsskriftet til Det Norske Medicinske Selskab, Michael Quarterly, som gir en gjennomgang av dette perspektivet med kronisk utmattelsessyndrom-diagnosen som en «rød tråd» (4). Artikkelen gir også utfyllende svar og tolkninger på noen av de spørsmålene som Tveito stiller.

Jeg ser det som nødvendig at forskning med det målet å få fram ulike hypoteser og mer kunnskap omkring CFS/ME, også innbefatter å undersøke biografiske «data» om menneskers erfaringer. Det vil kunne bringe oss viktige skritt videre i å forstå tilstanden og kunne gi hjelp som nytter.

\section{LITTERATUR}

1. Tveito K. Det er så mye vi ikke vet. Tidsskr Nor Legeforen 2014; 134: 1117. [PubMed]

2. Merleau-Ponty M. Phénoménologie de la perception. Paris: Gallimard, 1945.

3. Kirkengen AL. Hvordan krenkede barn blir syke voksne. 2. utg. Oslo: Universitetsforlaget, 2009. English translation: Kirkengen AL. The lived experience of violation. How abused children become unhealthy adults. Bucuresti: Zeta Books, 2010.

4. Eid JT. Levd kropp - en analyse av Anna Luise Kirkengens tenkning. Michael 2012; 9: 254-67. 
Publisert: 2. september 2014. Tidsskr Nor Legeforen. DOI: 10.4045/tidsskr.14.0912

(C) Tidsskrift for Den norske legeforening 2023. Lastet ned fra tidsskriftet.no 26. april 2023. 